\title{
Parechovirus Infection Mimicking Bacterial Sepsis in an Infant
}

\section{Bir Infantta Bakteriyel Sepsisi Taklit Eden Parekovirüs Enfeksiyonu}

\author{
Döndü Nur Tokmak'(iD), Rumeysa Yalçınkaya²(iD ), Nazlı Gülenç(ID), Fatma Nur Öz²(iD), Ayşe Kaman²(iD), \\ Türkan Aydın Teke²(ID), Sevgi Yaşar Durmuş²(ID), Gönül Tanır²(iD) \\ ${ }^{1}$ Clinic of Pediatrics, Ankara Dr. Sami Ulus Maternity and Children Research and Training Hospital, Ankara, Turkey \\ ${ }^{2}$ Clinic of Pediatric Infectious Diseases, Ankara Dr. Sami Ulus Maternity and Children Research and Training Hospital, Ankara, Turkey
}

Cite this article as: Tokmak DN, Yalçınkaya R, Gülenç N, Öz FN, Kaman A, Aydın Teke T, et al. Parechovirus infection mimicking bacterial sepsis in an infant. J Pediatr Inf 2021;15(1):e45-e48.

\section{Abstract}

Human parechoviruses ( $\mathrm{HPeV}$ ) are responsible for gastrointestinal and respiratory system infections which are seen mostly in the first year of life. It is known that HPeV may cause sepsis like syndrome and meningoencephalitis in neonates and infants. Although the prognosis of central nervous system infections caused by $\mathrm{HPeV}$ are suggested to be quite good and similar to enteroviruses, there are reports of severe cases which cause encephalitis and neurological sequels. The use of polymerase chain reaction (PCR) test in diagnosis may reduce antibiotic use and length of hospital stay. There are no specific antiviral agents for treatment. This is a report of a 38-day-old febrile infant admitted with a sepsis-like clinical condition and diagnosed with HPeV meningitis through cerebrospinal fluid PCR test.

Keywords: Parechovirus, sepsis, infant, meningitis

\section{Introduction}

Human parechoviruses (HPeV) are single-stranded RNA viruses belonging to the picornavirus family. There are 19 subtypes identified until today. HPeV-1 and HPeV-3 are the subtypes most frequently causing diseases in humans. It is known that HPeV-3 often leads to fulminant hepatitis, sepsis-like
Öz

İnsan parekovirüsleri (HPeV), sıklıkla doğumdan sonraki ilk yıl içinde görülen gastrointestinal ve respiratuvar sistem enfeksiyonlarından sorumludur. Yenidoğanlarda ve süt çocuklarında sepsis benzeri sendrom ve meningoensefalite neden oldukları bilinmektedir. Genelde HPeV'in sebep olduğu santral sinir sistemi (SSS) enfeksiyonlarının klinik gidişinin enterovirüslerin seyrine benzediği ve iyi seyirli olduğu düşünülse de, ensefalit ve nörolojik sekellere sebep olan ağır tablolar da bildirilmiştir. Polimeraz zincir reaksiyonu (PZR) testinin kullanılarak etkenin gösterilmesi, hastanede yatış süresini kısaltabilir ve antibiyotik kullanımını azaltabilir. Tedavide önerilen özgül bir antiviral ajan yoktur. Burada, sepsis benzeri bir klinik ile başvuran ve beyin omurilik sIVISı (BOS) PZR tetkiki ile parekovirüs menenjiti tanısı alan 38 günlük, yüksek ateşli bir süt çocuğu sunulmuştur.

Anahtar Kelimeler: Parekovirüs, sepsis, infant, menenjit

disease and meningoencephalitis in neonates and rash with prolonged fever in infants younger than 6 months (1). They are also held responsible for gastrointestinal and respiratory system infections in the first year following birth.

Due to the insufficiency of routine testing, its true incidence is not known. Generally, even though it is considered

\section{Correspondence Address / Yazışma Adresi}

\section{Rumeysa Yalçınkaya}

Ankara Dr. Sami Ulus Kadın Doğum Çocuk Sağlığı ve Hastalıkları

Eğitim ve Araştırma Hastanesi,

Çocuk Enfeksiyon Hastalıkları Kliniği,

Ankara-Türkiye

E-mail: rumeysa_ra@hotmail.com 
that central nervous system (CNS) infections caused by HPeV have a similar course with that of enteroviruses and a good prognosis, there have been reports of severe clinical manifestations with encephalitis and neurological damage (2). Determining the agent using polymerase chain reaction (PCR) test may shorten length of hospital stay and reduce antibiotic use. There is no specific antiviral agent recommended for treatment. Since they cause self-limiting diseases with good prognosis, supportive treatment and treatment of complications, when necessary, are recommended.

This is a report of a 38-day-old febrile infant presenting with a sepsis-like clinic and diagnosed with parechovirus meningitis with cerebrospinal fluid (CSF) PCR test.

\section{Case Report}

A 38-day-old male patient presented with fever and uneasiness ongoing for two days. It was found that the fever was $40^{\circ} \mathrm{C}$ the highest and had not responded to antipyretics. On physical examination, the patient was moderate, and he was unease and agitated. Extensive cutis marmoratus covering the whole body was observed. Body temperature was detected as $37.9^{\circ} \mathrm{C}$, respiratory rate as $80 / \mathrm{min}$, heart rate as $193 /$ $\mathrm{min}$, blood pressure as $80 / 40 \mathrm{mmHg}$, and oxygen saturation in room air as $99 \%$. Other system examinations were normal. Intravenous fluid administration was applied to the patient who developed tachycardia and symptoms of hypoperfusion. The patient continued to be followed by starting inotropic treatment since his hypoperfusion symptoms persisted despite fluid administration. All septic evaluations of the patient including lumbar puncture (LP) were performed and cultures taken, and the patient was started on ampicillin ( $200 \mathrm{mg} / \mathrm{kg} /$ day) and cefotaxime ( $200 \mathrm{mg} / \mathrm{kg} /$ day) with a preliminary diagnosis of sepsis.

Laboratory investigations showed white blood cell count $9.030 / \mathrm{mm}^{3}$ ( $60 \%$ polymorphonuclear, $36 \%$ lymphomonocyte) hemoglobin $10.5 \mathrm{~g} / \mathrm{dL}$, thrombocyte count $651.000 / \mathrm{mm}^{3}$, C-reactive protein (CRP) $7.64 \mathrm{mg} / \mathrm{L}$ (Normal: 0-4 mg/L), and his biochemical parameters were normal. Cerebrospinal fluid was hemorrhagic and had plentiful erythrocytes in cell count. CSF protein level was $195 \mathrm{mg} / \mathrm{dL}$, CSF glucose level was $47 \mathrm{mg} /$ $\mathrm{dL}$ and simultaneous blood glucose was $88 \mathrm{mg} / \mathrm{dL}$. Due to patient's age, sepsis-like clinic and CSF findings, acyclovir (30 $\mathrm{mg} / \mathrm{kg} /$ day) was added to his treatment considering herpes simplex virus in preliminary diagnosis.

It was seen in his repetitive physical examination that maculopapular rashes blanching under pressure had developed on his truncus and extremities (Figures 1,2). Due to fever ongoing for five days, persistent uneasiness and rash, the patient was considered to have Kawasaki shock syndrome that could cause sepsis-like picture in this age group, and echocardiography was performed twice and found normal. Transfontanelle

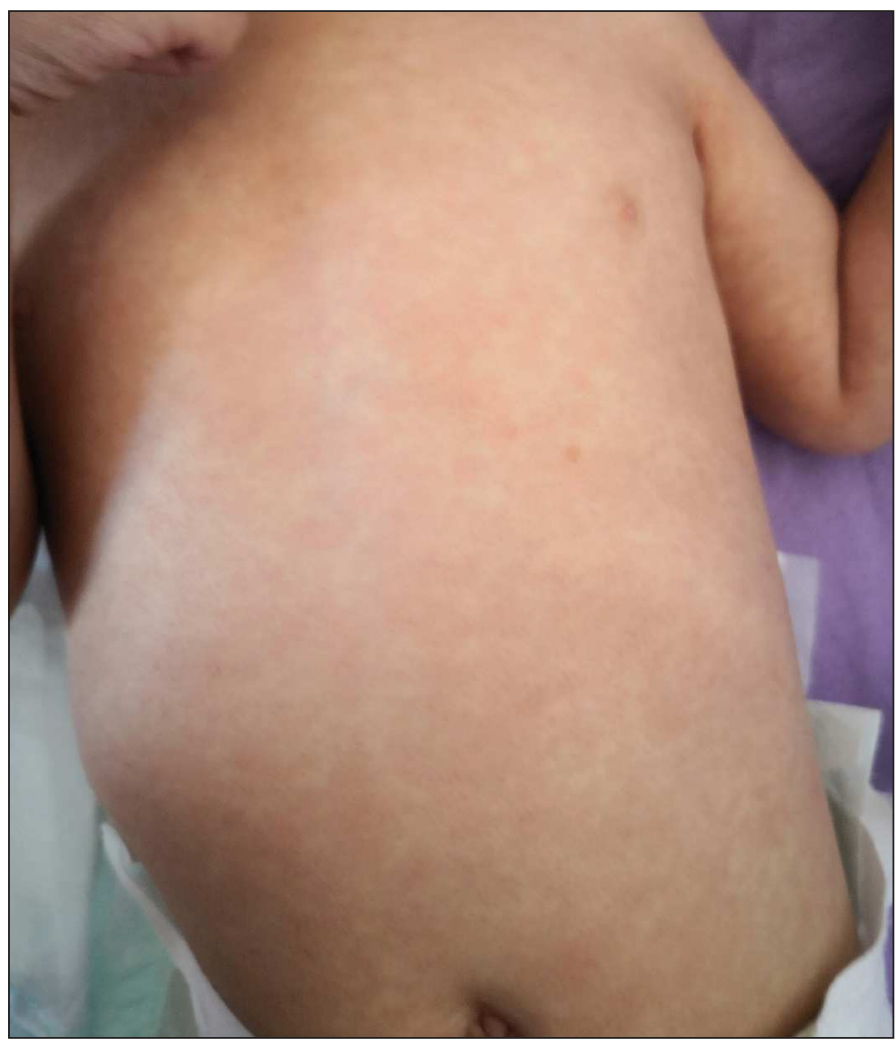

Figure 1. Maculopapular rash on the truncus that blanch under pressure.

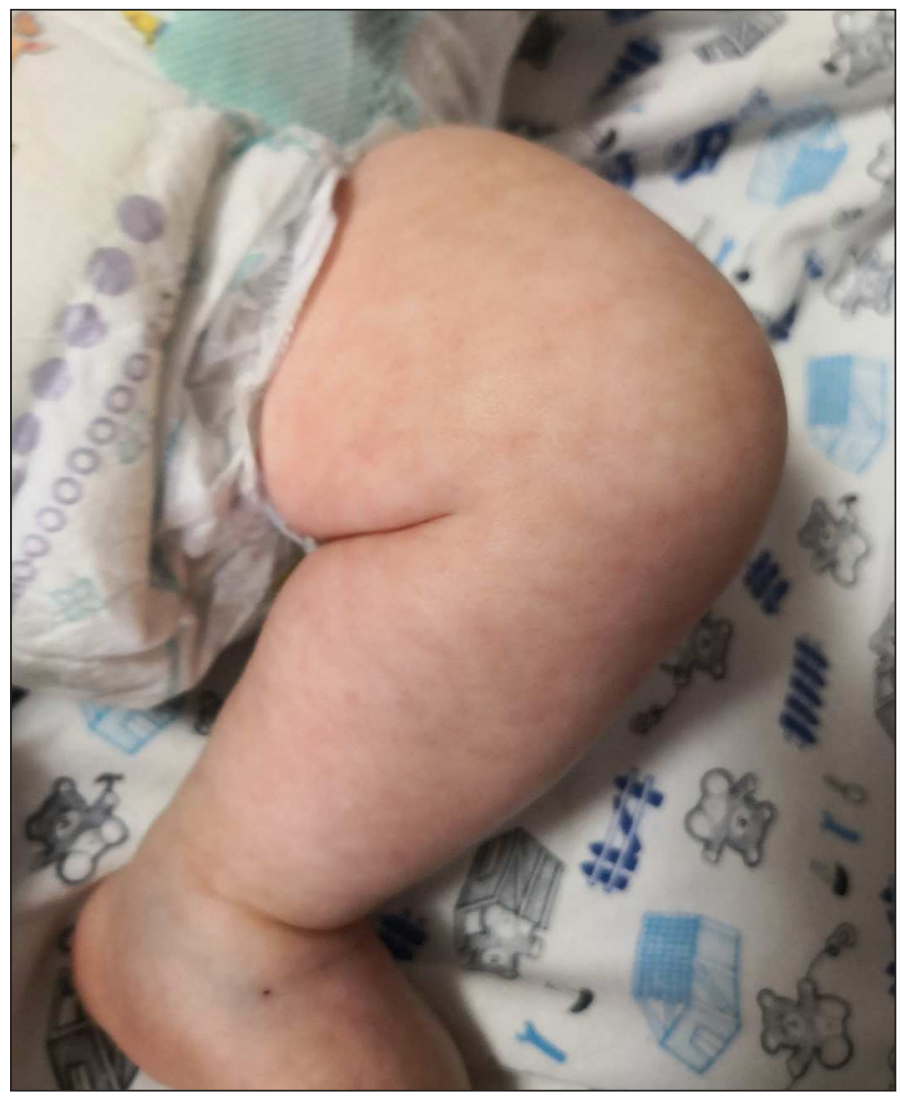

Figure 2. Maculopapular rash on lower extremities that blanch under pressure. 
ultrasonography and abdominal ultrasonography were normal.

Parechovirus DNA was detected positive in the CSF PCR of the patient whose fever persisted for 2 more days (enterovirus and herpes simplex virus were negative).

Antibiotic treatments of the patient whose blood, urine and CSF did not show growth were terminated, and acyclovir treatment was also ended since CSF herpes virus DNA was found negative. The patient, whose fever and rashes regressed, was discharged on the sixth day of hospitalization. Control examination that took place 1 week later was normal. Patient is being followed as a healthy child.

\section{Discussion}

It may be difficult to differentiate between serious bacterial infection and self-limiting viral disease in 1-3-month-old infants with fever of unknown origin. There are some protocols that are used to determine infants carrying a low risk in terms of serious bacterial infection and that enable outpatient follow. Infants who look critically ill (toxic, septic) should be hospitalized and started on parenteral antibiotic treatment (3). Our case presented with fever of unknown origin and was planned to undergo septic evaluation by being hospitalized. Intravenous fluid administration was applied to the patient who developed tachycardia and symptoms of hypoperfusion, and empirical ampicillin and cefotaxime treatments were started with a preliminary diagnosis of sepsis. During follow, the patient received $\mathrm{HPeV}$ diagnosis upon confirming PCR positivity in CSF.

Clinical symptoms on presentation of HPeV in neonates and infants are fever, uneasiness, and atypical rash. This is defined as "hot, red, and angry babies" (4). A sepsis-like manifestation and CNS involvement that is hard to differentiate clinically from bacterial sepsis can be seen. In a retrospective study carried out in CSF samples of children aged younger than 5 years presenting with sepsis-like diseases, it has been detected that severe $\mathrm{HPeV}$ infections are seen apart from the neonatal period, and median age has been determined as 4 weeks and the oldest case has been reported as aged 10 weeks (5). Our case was a 5 -week-old neonate who presented with fever and uneasiness and developed atypical rash during monitoring and followed for sepsis-like disease and received parechovirus infection diagnosis with CSF PCR. Three neonate sepsis cases caused by HPeV-3 were reported in Canada in 2005. All presented with fever, maculopapular rash and tachypnea, and two cases were reported to have developed thrombocytopenia and leukocytosis (60\% lymphocyte) (6). This case was presented to remind that $\mathrm{HPeV}$ infections must be considered in differential diagnosis in neonates and infants presenting with fever and uneasiness, having atypical rash, and developing sepsis-like disease manifestations.
There have been cases reporting severe neurologic damage or morbidity of the disease that usually has a mild course and is recovered (7). Other than sepsis-like disease, $\mathrm{HPeV}$ infection may lead to various clinical pictures such as acute liver failure (8), hepatitis (9), myocarditis (10), myalgia and myositis (11), apnea (12), sudden infant death syndrome (13), and hemophagocytic lymphohistiocytosis (14).

Early diagnosis and detection of the agent with PCR is important in patients with mild and moderate diseases as it reduces antibiotic use and shortens length of hospital stay. In infants aged younger than 6 months with no other confirmed diagnosis, the use of molecular diagnostic method for $\mathrm{HPeV}$ is recommended in cases of febrile disease, shock, sepsis-like clinic and suspected meningoencephalitis (4). It has been reported in a study that HPeV-specific PCR addition in children younger than 5 years leads to a $31 \%$ increase in detecting neonatal sepsis or viral agent of CNS symptoms (5). In a study evaluating children younger than 5 years with sepsis-like disease and meningitis, it has been established that $78.5 \%$ of $\mathrm{HPeV}$ cases remain undiagnosed with only routine CSF examinations (cell count, glucose, protein). The importance of testing CSF samples for viral agents without a scanning criterion has been emphasized. (15). In a study performed in the UK, it has been reported that the frequency of $\mathrm{HPeV}$ meningitis in infants confirmed by laboratory tests is twofold the frequency of bacterial meningitis (16).

There is no specific antiviral treatment recommended for $\mathrm{HPeV}$. Principles of general care, supportive treatment, close monitoring for organ involvements, treatment of complications, and diagnostic tests to confirm infection are fundamental steps in patient management.

\section{Conclusion}

Viral causes particularly like parechovirus must be kept in mind in neonates and infants presenting with fever, meningoencephalitis and sepsis-like disease, and the use of molecular methods like PCR must be generalized to reduce antibiotic use and have rapid diagnosis.

Informed Consent: Patient consent was obtained.

Peer-review: Externally peer-reviewed.

Author Contributions: Concept - RY, DNT, NG, GT; Design - RY, AK, SYD, FNÖ; Supervision - RY, FNÖ, TAT, GT; Resources - All of authors; Data Collection and/or Processing - RY, SYD, AK, DNT, NG; Analysis and/or Interpretation - FNÖ, AK, TAT; Literature Review - RY, DNT, SYD, NG; Writing - DNT, RY, GT; Critical Review - GT, FNÖ, TAT.

Conflict of Interest: No conflict of interest was declared by the authors.

Financial Disclosure: The authors declared that this study has received no financial support. 


\section{References}

1. Verboon-Maciolek MA, Krediet TG, Gerards LJ, de Vries LS, Groenendaal $F$, van Loon AM. Severe neonatal parechovirus infection and similarity with enterovirus infection. Pediatr Infect Dis J 2008;27(3):241-5. [CrossRef]

2. Park SE, Song D, Shin K, Nam SO, Ko A, Kong J, et al. Prospective research of human parechovirus and cytokines in cerebrospinal fluid of young children less than one year with sepsis-like illness: Comparison with enterovirus. J Clin Virol 2019;119:11-6. [CrossRef]

3. Kliegman R, Stanton B, Geme JW, Schor NF, Behrman RE, Nelson WE. Nelson Textbook of Pediatrics. $21^{\text {st }}$ ed. Philadelphia: Elsevier; 2020. 2 volumes $p$. [CrossRef]

4. Britton PN, Jones CA, Macartney K, Cheng AC. Parechovirus: an important emerging infection in young infants. Med J Aust 2018;208(8):365-9. [CrossRef]

5. Wolthers KC, Benschop KS, Schinkel J, Molenkamp R, Bergevoet RM, Spijkerman IJ, et al. Human parechoviruses as an important viral cause of sepsislike illness and meningitis in young children. Clin Infect Dis 2008;47(3):358-63. [CrossRef]

6. Levorson RE, Jantausch BA, Wiedermann BL, Spiegel HM, Campos JM. Human parechovirus-3 infection: emerging pathogen in neonatal sepsis. Pediatr Infect Dis J 2009;28(6):545-7. [CrossRef]

7. Jones M. Human parechovirus in infants: An emerging virus in Australia with severe neurodevelopmental implications. J Paediatr Child Health 2017;53(3):306-8. [CrossRef]

8. Bigelow $A M$, Scott JP, Hong JC, Cronin DC, Vitola BE, Fons RA, et al. Human parechovirus as a cause of isolated pediatric acute liver failure. Pediatrics 2016;138(5). [CrossRef]
9. Khatami A, McMullan BJ, Webber M, Stewart P, Francis S, Timmers KJ, et al. Sepsis-like disease in infants due to human parechovirus type 3 during an outbreak in Australia. Clin Infect Dis 2015;60(2):228-36. [CrossRef]

10. Mardekian SK, Fortuna D, Nix A, Bhatti T, Wiley CA, Flanders $A$, et al. Severe human parechovirus type 3 myocarditis and encephalitis in an adolescent with hypogammaglobulinemia. Int J Infect Dis 2015;36:6-8. [CrossRef]

11. Mizuta K, Yamakawa T, Kurokawa K, Chikaoka S, Shimizu Y, Itagaki T, et al. Epidemic myalgia and myositis associated with human parechovirus type 3 infections occur not only in adults but also in children: findings in Yamagata, Japan, 2014. Epidemiol Infect 2016;144(6):1286-90. [CrossRef]

12. Nirei J, Aizawa Y, Okazaki M, Kobayashi A, Onozuka J, Numata O, et al. Human parechovirus type 3 infection: cause of apnea in infants born prematurely. Pediatr Int 2016;58(5):400-2. [CrossRef]

13. Sedmak G, Nix WA, Jentzen J, Haupt TE, Davis JP, Bhattacharyya S, et al. Infant deaths associated with human parechovirus infection in Wisconsin. Clin Infect Dis 2010;50(3):357-61. [CrossRef]

14. Aviner S, Sofer D, Shulman LM, Bibi H, Weitzman S. Hemophagocytic lymphohistiocytosis associated with parechovirus 3 infection. J Pediatr Hematol Oncol 2014;36(4):e251-3. [CrossRef]

15. Chakrabarti P, Warren C, Vincent L, Kumar Y. Outcome of routine cerebrospinal fluid screening for enterovirus and human parechovirus infection among infants with sepsis-like illness or meningitis in Cornwall, UK. Eur J Pediatr 2018;177(10):1523-9. [CrossRef]

16. Kadambari S, Braccio S, Ribeiro S, Allen DJ, Pebody R, Brown D, et al. Enterovirus and parechovirus meningitis in infants younger than 90 days old in the UK and Republic of Ireland: a British Paediatric Surveillance Unit study. Arch Dis Child 2019;104(6):552-7. [CrossRef] 